\title{
Bilateral vestibulopathy in anti-IgLON5 disease
}

\author{
Christoph Helmchen ${ }^{1,5} \cdot$ Klaus-Peter Wandinger $^{2} \cdot$ Armin Steffen $^{3} \cdot$ Thomas F. Münte $^{1,5} \cdot$ Norbert Brüggemann $^{1,4,5}$
}

Received: 19 August 2020 / Revised: 30 September 2020 / Accepted: 21 December 2020 / Published online: 23 January 2021

(c) The Author(s) 2021

\section{Dear Sirs,}

Anti-IgLON5 disease was first described in 2014 and is characterized by non-REM and REM parasomnias, obstructive sleep apnea and neurological manifestations affecting the central nervous system in association with antibodies against extracellular epitopes of IgLON5, a neuronal cell adhesion protein $[3,7]$. IgLON5 antibodies are highly specific and the diagnosis can additionally be corroborated by the analysis of the human leukocyte antigens HLADRB $1 * 10: 01$ and HLA-DQB $1 * 05: 01$ which can be detected in $87 \%$ of patients $[3,6]$. Neurological signs of the anti-IgLON5 disease [7] are manifold and comprise bulbar signs, a syndrome resembling progressive supranuclear palsy [1], cognitive decline, gait abnormalities and ataxia. Although signs of additional peripheral neuropathy have recently been reported in a few patients [8], vestibular dysfunction as a potential cause

Christoph Helmchen

christoph.helmchen@neuro.uni-luebeck.de

Klaus-Peter Wandinger

klaus-peter.wandinger@uksh.de

Armin Steffen

armin.steffen@uksh.de

Thomas F. Münte

thomas.muente@neuro.uni-luebeck.de

Norbert Brüggemann

norbert.brueggemann@neuro.uni-luebeck.de

1 Department of Neurology, University Hospital Schleswig Holstein, University of Lübeck, Campus Lübeck, Ratzeburger Allee 160, 23538 Lubeck, Germany

2 Institute of Clinical Chemistry, University Hospital Schleswig-Holstein, Lübeck, Germany

3 Department of Otorhinolaryngology, University Hospital Schleswig-Holstein, Lübeck, Germany

4 Institute of Neurogenetics, University of Lübeck, Lübeck, Germany

5 Center of Brain, Behavior and Metabolism (CBBM), University of Lübeck, Ratzeburger Allee 160, 23562 Lübeck, Germany of gait unsteadiness has not been described previously in patients with IgLON5 antibodies.

Here, we report an IgLON5-antibody-positive 74-yearold woman with severe bilateral vestibulopathy (BV) suffering from long-standing (12 years) progressive gait unsteadiness. Gait instability increased with head movements and in darkness. She had noticed tingling and paresthesia in her lower legs for about the same time.

Follow-up clinical (head impulse test) and quantitative testing revealed severe progressive bilateral vestibulopathy and some clinical [reduced tendon reflexes in the legs, moderately reduced vibration sense at the ankles] but no neurographic evidence for polyneuropathy over years. Romberg test was pathological and she showed a moderately broadbased gait. Oculomotor and the rest of the neurological examination were normal.

Laboratory examinations were negative for routine work up for polyneuropathies, including cerebrospinal fluid. Strikingly, antibodies against IgLON5 (serum 1:10,000; CSF 1:32) were found as well as the IgLON5-associated HLADRB1*10:01/HLA-DQB1*05:01 haplotype. Additional antibody screening was negative for $\mathrm{GABA}_{\mathrm{B}}$, GAD, LGI1, CASPR2, ANA, gangliosides GM1 and GM2, and GQ1b. Cancer screening was negative. Genetically, the RFCl pentanucleotide expansion was excluded ruling out CANVAS [5]. Screening for viral and bacterial agents remained negative except for IgG antibodies against the VlsE-antigen and IgM antibodies against the OspC antigen of Borrelia burgdorferi. In the absence of symptoms of a previous Lyme disease she was treated with doxycyclin but gait unsteadiness deteriorated.

Vestibular testing [10] revealed severe vestibular hypofunction with reduced gain of the vestibulo-ocular reflex (VOR) during quantitative head impulse testing, nearly absent responses to caloric irrigation (Fig. 1) and vestibular chair rotation and absent ocular vestibular evoked myogenic potentials. Subjective visual vertical was normal. Cranial MRI was normal. A type 4 home sleep test using peripheral arterial tone $\left(\right.$ WatchPAT ${ }^{\circledR}$, Itamar) revealed an apnea/hypopnea index of $13.3 / \mathrm{h}$ (normal range: $<5 / \mathrm{h}$ ) 
Fig. 1 Quantitative head impulse testing (EyeSeeCam ${ }^{\circledR}$ ) of the horizontal vestibuloocular reflex 6 (a) and 11 years (b) after symptom onset with progressive vestibular hypofunction and nearly absent responses to caloric irrigation (c), to chair rotation and absent ocular vestibular evoked myogenic potentials a

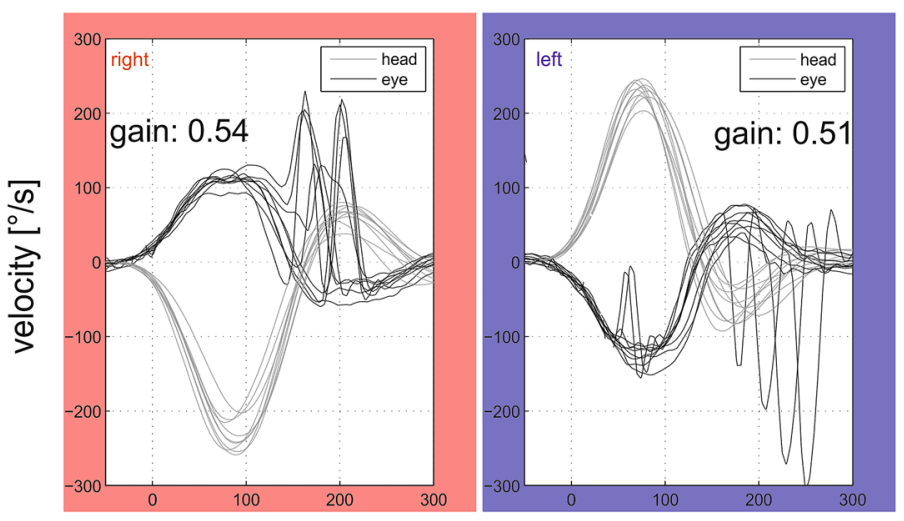

b
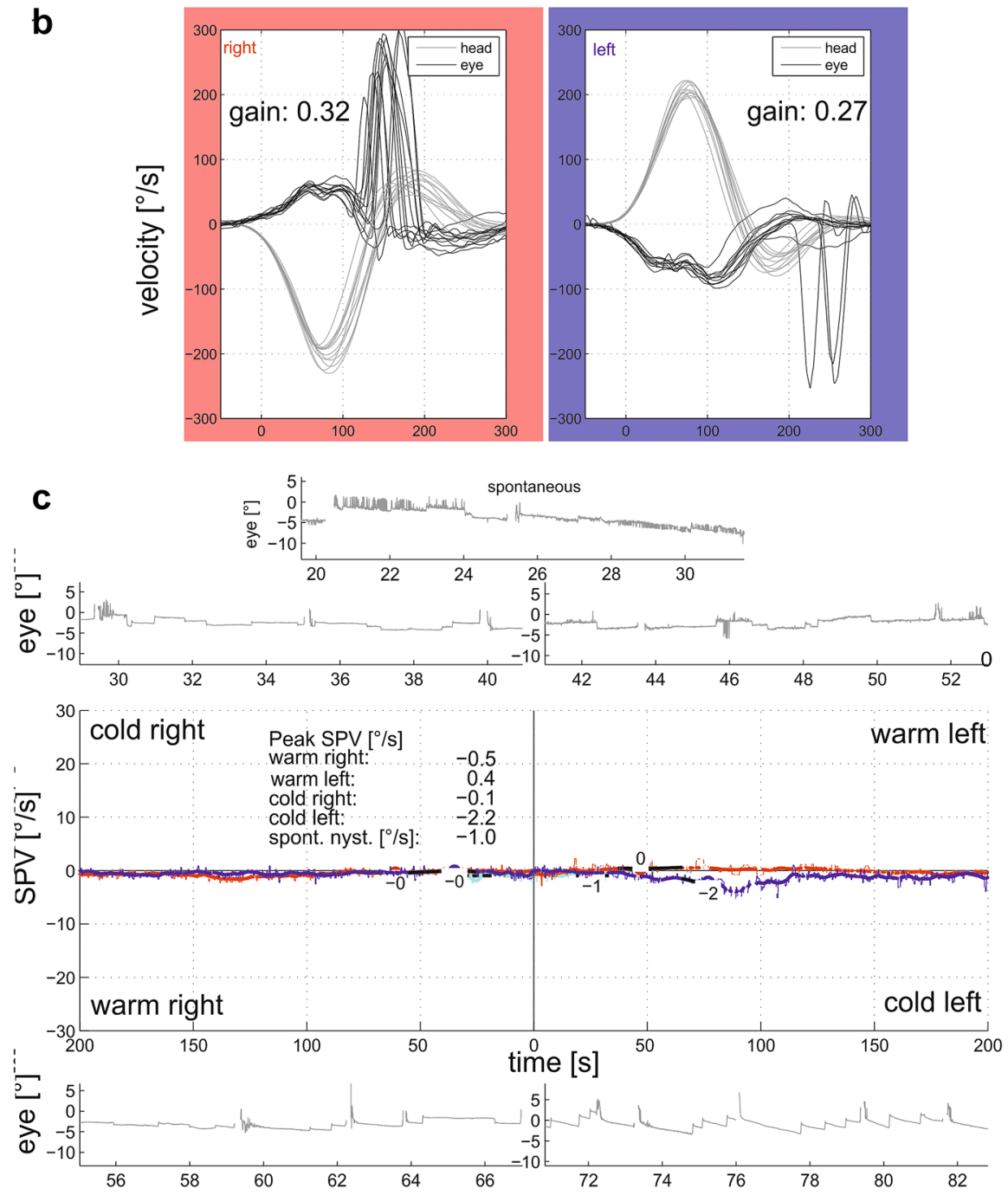

for the entire night, $26.6 / \mathrm{h}$ during REM sleep and 30.8/h for supine position [9]. The oxygen desaturation index was $6.2 / \mathrm{h}$ for the entire night (REM sleep: $15.8 / \mathrm{h}$, supine position: $19.6 / \mathrm{h}$, abnormal: $>15$ events/h) with normal blood oxygen saturation (96\%), and a reduced minimal oxygen saturation of $84 \%$ in this normal weighted patient (BMI $22 \mathrm{~kg} / \mathrm{m}^{2}$ ). Sleep latency was normal (19 $\mathrm{min}$ ), but shortened for REM sleep (29 min). The distribution of REM (23.9\%) and deep sleep (22.2\%) was normal. There were no signs of insomnia (sleep efficacy $88.3 \%$, number of wakes per night 4). Daytime sleepiness was within normal limits (Epworth Sleepiness Scale 2 out of 24 points). Based on the detection of IgLON5 antibodies in 2019 
she was initially treated with immunoglobulins and with rituximab for the last 3 months.

The combination of a high titer of antibodies against IgLON5 epitopes in serum and CSF, the HLA haplotype and sleep apnea and the exclusion of other known causes of $\mathrm{BV}$ makes it possible that $\mathrm{BV}$ in this patient reflects an additional sign of anti-IgLON5 disease. Post-mortem investigations of patients with anti-IgLON5 disease revealed the vestibular nuclei to contain the most extensive tau pathology in the brainstem [4], but peripheral vestibular nerve was not examined. Here, we provide some evidence that (i) $\mathrm{BV}$ is the major reason for gait unsteadiness in this patient with IgLON5 antibodies and that (ii) vestibular hypofunction is caused by peripheral vestibular organ damage. We, therefore, suggest that IgLON5 antibodies may damage the peripheral vestibular organ/nerve by a hitherto unknown mechanism which could reflect a previously unrecognized and potentially treatable reason for slowly progressive gait unsteadiness in "idiopathic" BV [2]. IgLON5-related $\mathrm{BV}$ may enlarge the multisystemic phenotype of this new disease.

Acknowledgements The authors wish to thank Dr. Katja Lohmann for the genetic analysis of the RFC1 gene.

Author contributions Design/conceptualization of the study: $\mathrm{CH}, \mathrm{NB}$; analysis/interpretation of the data: all authors; polysomnography: AS; antibodies and HLA studies: KPW; drafting the manuscript: $\mathrm{CH}$; revising the manuscript: all authors.

Funding Open Access funding enabled and organized by Projekt DEAL.

\section{Compliance with ethical standards}

Conflicts of interest C. Helmchen received honoraria from Sensorion, Heel, Schwabe, Pierre Fabre. K.P.Wandinger reports no disclosures relevant to the manuscript; A. Steffen is a study investigator and received honoraria and travel expenses for invited talks on behalf of Inspire Medical, Inc. He serves as a consultant for Merz Pharmaceuticals and received honoraria for expert meetings from Proveca Ltd. T.F. Münte is funded by the DFG (MU1311/16-2, 17-1, 20-1, CRC/TR296) and BMBF (01GJ1303B). N. Brüggemann received speaker's honoraria from Grünenthal, UCB, Abbvie and Teva. He served as a consultant for Censa Pharmaceuticals and Centogene. He received nonfinancial support from Bayer. NB is funded by the DFG (BR4328.2-2, GRK1957), the Collaborative Center for X-linked Dystonia-Parkinsonism and the Else-Kröner Fresenius-Stiftung (HA17_2017).

Ethical standards The authors assure that the work was conducted in line with the ethical standards of the Journal of Neurology.

Open Access This article is licensed under a Creative Commons Attribution 4.0 International License, which permits use, sharing, adaptation, distribution and reproduction in any medium or format, as long as you give appropriate credit to the original author(s) and the source, provide a link to the Creative Commons licence, and indicate if changes were made. The images or other third party material in this article are included in the article's Creative Commons licence, unless indicated otherwise in a credit line to the material. If material is not included in the article's Creative Commons licence and your intended use is not permitted by statutory regulation or exceeds the permitted use, you will need to obtain permission directly from the copyright holder. To view a copy of this licence, visit http://creativecommons .org/licenses/by/4.0/.

\section{References}

1. Bruggemann N, Wandinger KP, Gaig C, Sprenger A, Junghanns K, Helmchen C, Munchau A (2016) Dystonia, lower limb stiffness, and upward gaze palsy in a patient with IgLON5 antibodies. Mov Disord 31:762-764

2. Fujimoto C, Yagi M, Murofushi T (2019) Recent advances in idiopathic bilateral vestibulopathy: a literature review. Orphanet J Rare Dis 14:202

3. Gaig C, Graus F, Compta Y, Hogl B, Bataller L, Bruggemann N, Giordana C, Heidbreder A, Kotschet K, Lewerenz J, Macher S, Marti MJ, Montojo T, Perez-Perez J, Puertas I, Seitz C, Simabukuro M, Tellez N, Wandinger KP, Iranzo A, Ercilla G, Sabater L, Santamaria J, Dalmau J (2017) Clinical manifestations of the anti-IgLON5 disease. Neurology 88:1736-1743

4. Gelpi E, Hoftberger R, Graus F, Ling H, Holton JL, Dawson T, Popovic M, Pretnar-Oblak J, Hogl B, Schmutzhard E, Poewe W, Ricken G, Santamaria J, Dalmau J, Budka H, Revesz T, Kovacs GG (2016) Neuropathological criteria of anti-IgLON5-related tauopathy. Acta Neuropathol 132:531-543

5. Gisatulin M, Dobricic V, Zühlke C, Hellenbroich Y, Tadic V, Münchau A, Isenhardt K, Bürk K, Bahlo M, Lockhart PJ, Lohmann K, Helmchen C, Brüggemann N (2020) Clinical spectrum of the pentanucleotide repeat expansion in the RFC1 gene in ataxia syndromes. Neurology 95(21):e2912-e2923. https://doi. org/10.1212/WNL.0000000000010744

6. Hasselbacher K, Steffen A, Wandinger KP, Bruggemann N (2018) IgLON5 antibodies are infrequent in patients with isolated sleep apnea. Eur J Neurol 25:e46-e47

7. Honorat JA, Komorowski L, Josephs KA, Fechner K, St Louis EK, Hinson SR, Lederer S, Kumar N, Gadoth A, Lennon VA, Pittock SJ, McKeon A (2017) IgLON5 antibody: neurological accompaniments and outcomes in 20 patients. Neurol Neuroimmunol Neuroinflamm 4:e385

8. Nissen MS, Blaabjerg M (2019) Anti-IgLON5 disease: a case with 11-year clinical course and review of the literature. Front Neurol 10:1056

9. Sabater L, Gaig C, Gelpi E, Bataller L, Lewerenz J, Torres-Vega E, Contreras A, Giometto B, Compta Y, Embid C, Vilaseca I, Iranzo A, Santamaria J, Dalmau J, Graus F (2014) A novel nonrapid-eye movement and rapid-eye-movement parasomnia with sleep breathing disorder associated with antibodies to IgLON5: a case series, characterisation of the antigen, and post-mortem study. Lancet Neurol 13:575-586

10. Sprenger A, Wojak JF, Jandl NM, Helmchen C (2017) Postural control in bilateral vestibular failure: its relation to visual, proprioceptive, vestibular, and cognitive input. Front Neurol 8:444 